\title{
EENIGE LICHTPUNTEN VOOR HET STELSEL VAN VRIJHANDEL.
}

In den laatsten tijd geldt in bijna alle landen van Europa en in de Vereenigde Staten van Noord-Amerika de protectie. En zelfs in de beide landen van Europa, met name in Engeland en Nederland, waar de protectie nog niet is toegepast, steken de voorstanders van dat stelsel het hoofd meer omhoog. Voor hen, die gelooven, dat bescherming nadeelig is voor de welvaart, is het dus een voldoening op te merken, dat er eene strooming in de politieke opinie tegen protectie begint te ontstaan. De volgende feiten bewijzen dit.

Het eerste feit is de boodschap van President Cleveland aan het congres der V. St. van N.-Amerika. Dat stuk is bijna geheel gewijd aan de finantien, te weten aan de middelen, om de inkomsten van den Staat minder te maken. De President wil dit bereiken, door de inkomende rechten te verlagen. Bij het motiveeren van dat voorstel gaat hij een stap verder, en betoogt hij het schadelijke van hooge inkomende rechten. Wel zegt hij daarbij, dat het geen belang heeft te onderzoeken, of dit de kwestie van vrijhandel of protectie raakt; maar zijn argumenten zijn dezelfden als die der freetraders. Hij zegt dat de inkomende rechten verminderd moeten worden tot het bedrag, dat noodig is voor de uitgaven van den staat. Dat is dus, wat de freetraders ook verlangen, een zuiver fiscaal recht. Hij zegt, dat de fabrikanten niet kunnen verlangen, zich door den staat buitengewone winsten verzekerd te zien, zonder acht te slaan op het algemeen welzijn; dat dit het geval zou zijn, als men wilde trachten 
te rechtvaardigen maatregelen, waardoor een belasting gelegd werd op elken verbruiker ten bate der fabrikanten; dat in de V. St. in de geprotegeerde fabrieken slechts $2 \frac{1}{2}$ millioen werklieden zijn, terwijl 15 millioen werklieden daarbuiten staan, die dus alleen de nadeelen hebben der protectie; dat de mededinging tusschen de beschermde fabrieken onderling dikwijls wordt voorkomen door combinatiën betreffende de fabrikage en de verhooging der prijzen.

Het tweede lichtpunt, boven bedoeld, is de redevoering, door Lord Salisbury, het hoofd van het conservatieve Kabinet in Engeland, onlangs te Derby gehouden. Hij heeft de fair-traders (bedekte protectionisten) erg in 't nauw gebracht door te zeggen, dat hij groote persoonlijke sympathie voor velen hunner had, maar dat hij gaarne zou zien, dat zij formuleerden, wat zij wilden, omdat hij hun verlangen niet begreep. Hij keurde het af, dat $z i j$ den landbouw wilden beschermen door een inkomend recht op graan, en vroeg of zij het brood voor den werkman duurder wilden maken? Dit vond hij verkeerd, omdat men dan schade zou doen aan de geheele industrie van Engeland, om een enkele industrie, den landbouw, te bevoordeelen.

Het derde feit, dat de aandacht verdient, is het voorloopig resultaat van de suikerconferentie te Londen. Men weet wat de kwestie is. De meeste staten van Europa, met uitzondering van Engeland, geven aan de beetwortelsuiker-fabrikant een premie op de fabrikage en uitvoer van beetwortelsuiker. Hoewel de suikerkwestie in de onderdeelen zeer ingewikkeld is, is de wijze, waarop die premie gegeven wordt, zeer eenvoudig. De belasting, de accijns, op de suiker wordt betaald door de suikerfabrikanten, en dezen krijgen die betaalde belasting terug, bij verkoop in het binnenland van de consumenten, bij uitvoer naar het buitenland van den staat. Wanneer nu die belasting geheven werd van de fabrikanten naar de 
werkelijke hoeveelheid suiker, die zij fabriceeren, zou alles goed gaan. Maar dat gebeurt niet. Die belasting wordt geheven, niet van de gefabriceerde suiker, maar van de grondst of fe $n$, waaruit de suiker gemaakt wordt. De staat neemt aan, dat uit een zekere kwantiteit beetwortels, of uit een zekere kwantiteit sap van beetwortels, een bepaalde kwantiteit suiker gemaakt wordt, en naar die geschatte hoeveelheid suiker betaalt de fabrikant de belasting. Maar nu haalt de fabrikant uit de beetwortels of uit het sap veel meer suiker dan de staat aanneemt. Dat meerdere, de zoogenaamde overponden, heeft dus de fabrikant vrij van accijns. En als hij die suiker uitvoert, krijgt hij van den staat accijns terug, die hij niet betaald heeft. Dit werkt dus als een premie op de fabrikage en den uitvoer van suiker. En die premie is niet gering. Terwijl de ruwe suiker, buiten den accijns, op dit oogenblik ca f 19 per 100 kilo kost, krijgt de fabrikant bij ons op die wijze minstens $f \mathbf{5}$ per 100 kilo premie op elke 100 kilo die hij fabriceert en uitvoert. Bij ons kost die ondersteuning meer dan 2 millioen gulden 's jaars aan den staat; in Duitschland zeker 24 millioen, in andere landen ook vele millioenen. $\mathrm{Om}$ aan die ongerijmdheid een einde te maken, is de suikerconferentie te Londen bijeen geweest. Ofschoon men uit den aard der zaak nog tot geen definitief resultaat is gekomen, is toch de lichtzijde der debatten deze, dat a lle staten de wenschelijkheid hehben uitgesproken, om aan die dwaze premien een einde te maken.

Zoodra de overtuiging maar doordringt, zoowel bij het publiek als bij de regeeringen, dat al die kunstmiddelen om eenige industrie te bevorderen op niets anders neerkomen, dan op het bevoordeelen van enkelen ten nadeele van het algemeen, zal de weg, om dat kwaad te verbeteren, van zelf wel gevonden worden.

M. MEes. 